\title{
Att äras eller glömmas
}

Av alla de skepp som under årtusenden existerat har de flesta för länge sedan seglat in i glömskans töcken. Ett litet fåtal har dock upphöjts och tilldelats verkliga hedersplatser i historien. Urvalet har skett på grundval av de stordåd som deras befälhavare anses ha uträttat. Fartyget är själva redskapet för bragderna och bedrifterna och åtnjuter inte sällan sin beskärda del av anseendet. Tänk på Christofer Columbus Santa Maria, Francis Drakes Golden Hind, Otto Nordenskiölds Vega, Thor Heyerdahls Kon-Tiki, James Cooks Endeavour eller Noaks ark.

Sjökrigande nationer upphöjer vanligtvis ett antal särskilt avgörande sjöslag och framstående hjältar. Skeppen som deltog i dessa bataljer och som fördes av legendariska amiraler får ofta framträdande platser i såväl berättelserna som högtidlighållandet av tilldragelserna. Som exempel vårdas amiral Lord Nelson skepp Victory som en nationalklenod på Royal Naval Dockyard i Portsmouth i södra England, medan Nederländernas store sjöhjälte Michiel de Ruyters skepp De Zeven Provinciën i skrivande stund återuppstår i form av en mycket påkostad fullskalekopia. Ett krigsfartyg med besättning kan liknas vid en kropp, vars vilja är befälhavarens. Sjöhjältens person framstår som intimt sammanflätad med skeppet.

Arkeologiska berättelser om stora örlogsfartyg kan rida på den trygga vågen som redan kända och bekanta episoder utgör, något som är särskilt tydligt när ett nytt vrakfynd kablas ut i media. Uppmärksamheten som undersökningar av skepp som tillhört en kung eller någon annan historisk celebritet får tycks alltid ge dylika projekt existensberättigande (se diskussion hos Cederlund 1997). Det allmänna intresset för sådana skeppsvrak är i grunden något positivt, men verksamheten ska inte reduceras till att återberätta välbekanta och ofta kraftigt förenklade episoder ur den stora berättelsen om den svenska nationen. Inte minst som dessa berättelser sållats fram enligt ideologiska premisser som många forskare av idag har svårt att förlika sig med. 
Urvalet som består av de historiska berättelser som omger oss idag har skett under lång tid och med särskilda syften. De uppbyggliga skrifterna Svenska sjöhjältar gavs ut i flera band med början strax före sekelskiftet 1900. Böckerna presenterade i högstämda ordalag de gamla stormaktssvenska sjökrigarna som förebilder och moraliska ledfyrar. Dylika skrifter är barn av sin tid och de högtravande och nationalistiska tongångarna kan idag kännas en smula obekväma. En arkeologi som inte kritiskt reflekterar över detta arv riskerar att reproducera dess värderingar.

Det finns därför anledning att titta närmare på hur händelseförloppet när de tre regalskeppen gick under har skildrats i historieskrivningen. Hur vraken har hanterats hänger nämligen samman med de eftermälen som de respektive skeppens befälhavare har fått i äldre historieskrivning. Det är dessa eftermälen som upprepas och förblir diffust närvarande när sensationella vrak upptäcks på havets botten.

\section{Skånska kriget och flottan}

Den svenska flottans nederlag och motgångar under skånska kriget är välkända. De skeenden som jag lyfter fram här är viktiga för att förstå varför Kronan och Svärdet har nått ikonstatus medan Riksäpplet närmast har förträngts. I korthet kan den svenska stormaktstidens krig beskrivas som en kamp om kontrollen över sjöfarten på Östersjön och handeln omkring. Danmark behärskade länge inloppet genom Öresund och kunde begära tull från passerande fartyg, medan Sverige blev allt mer dominerande på och runt Östersjön.

Nederländerna drog nytta av maktbalansen mellan Danmark och Sverige och understödde den svagare parten. I Roskildefreden erhöll Sverige bland annat Skåne, Blekinge, Halland och Bohuslän och med det andra danska kriget var Karl X Gustav på god väg att utplåna Danmark som nation. I det läget ansåg den såväl ekonomiska som militära supermakten att det svällande Stormaktssverige blivit alltför dominant och anslöt till Danmarks undsättning. Efter den svenska kungens plötsliga död slöts freden år I660.

Sedan Sverige genom alliansen med Frankrike åter hamnat i krig, såg Danmark en chans att återerövra de landskap som tidigare förlorats till Sverige. Danmark och Nederländernas allians kom att avsevärt påverka de sjömilitära styrkeförhållandena till svenskarnas nackdel. Under freden hade svenska flottan förvisso rustats rent materiellt och 
ett stort antal nya skepp hade byggts (för en översikt rörande skeppsbyggnadsprogrammet se Glete 2010:418-424), men ett förindustriellt krigsfartyg består dock till stor utsträckning av människor, hundratals människor. Den förhållandevis långa freden innebar att manskapet var oövat samt att erfarna befäl saknades. Amiralerna från Karl X Gustavs krig hade blivit gamla när orosmolnen åter hopade sig och flottan fick helt enkelt ta vad som fanns att tillgå i personalväg. I I6oo-talets Sverige var de högre ämbetena inom staten förbehållna adeln. Från en nutida horisont ter sig många av de rekryteringar som gjordes väldigt märkliga eftersom flera höga officerare helt saknade erfarenhet av sjön och i de flesta fall även av krig.

Bristen på rutin visade sig redan under hösten $\mathrm{I} 675$ då flottan ämnade undsätta de svenska provinserna i Pommern. Expeditionen leddes av Gustav Otto Stenbock (I614-I685), som förvisso var en gammal ärrad och välmeriterad krigare men som aldrig tjänat till sjöss trots att han titulerades riksamiral sedan elva år tillbaka. Expeditionen nådde aldrig längre än till uppsamlingsplatsen vid Karlsöarna innanför Gotland, där de överraskades av en storm. Skeppen började dragga. Elefanten med tjugo kanoner och Saltsäcken med sexton drev med ankarna släpande över botten mot land och krossades mot klipporna. Riksäpplet och Victoria miste sina ankaren. Mercurius kolliderade med skeppet Draken som förlorade fockmast och galjon. Flera skepp förlorade sina äspingar, småbåtarna de haft på släp.

Sedan sjukdomar dessutom börjat härja bland besättningarna vände flottan hem mot Stockholm utan att ens ha siktat fienden. Den misslyckade expeditionen kom att stå riksamiralen dyrt. Förutom att Stenbock förlorade sitt ämbete blev han ålagd att själv bekosta fiaskot, som ansågs ha kostat 209 34I daler silvermynt. Senare kom dock kungen att övertygas om Stenbocks välmening och bötessumman lindrades till roo ooo daler silvermynt (för en mer utförlig genomgång av Stenbocks expedition se Grandin 1985:98-I09; Lundgren 1997:48-63; Tornqvist I788:135-I40).

\section{Ny riksamiral}

I december I675 utsågs Lorentz Creutz (1615-1676) till amiral och amiralitetsråd med särskilt ansvar för ekonomin (fig. 2.I). Creutz var vid det laget en erkänt skicklig administratör med erfarenheter från framför allt Bergskollegium. Han var en person som gjort sig känd 


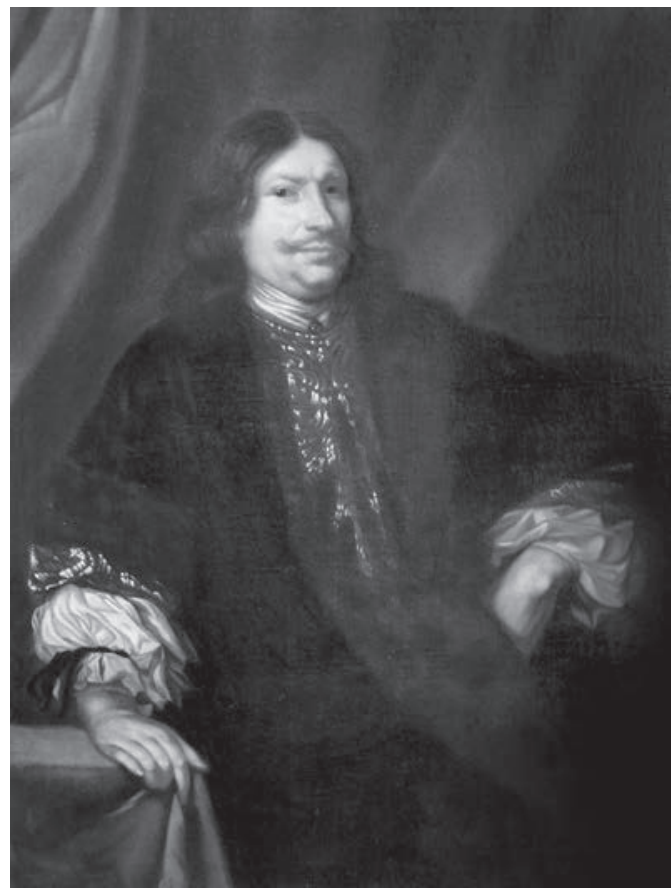

Fig. 2.1. Friherren Lorentz Creutz verkade som lagman, landshövding, riksråd, kammarråd och vice bergskollegiepresident. Under skånska kriget blev han utsedd till flottans högsta befäl. Målning av David Klöcker Ehrenstrahl. Foto: Nationalmuseum.

för att få sin vilja igenom. Till de meriter som från en nutida horisont kan framstå som mer egendomliga hör att han även varit ordförande i en trolldomskommission som dömde femton kvinnor till döden för häxeri. I början av april I676 blev Creutz tillförordnad chef för Amiralitetskollegium och han arbetade nitiskt för flottans utrustning. Tack vare hans administrativa talanger och hårdföra ledarstil lyckades man snart rusta flottan för ett nytt sjötåg. Trots sitt bristande sjömanskap tvekade han inte att också ta på sig ansvaret för högsta ledningen av operationerna till sjöss. (Lorentz d.ä. Creutz, urn:sbl:15662, Svenskt biografiskt lexikon (art. av Gr. Wittrock), hämtad 2017-04-03; för en omfattande biografi över släkten Creutz; se Lappalainen 2007). ${ }^{4}$

Flottan var vid denna tid förlagd till Skeppsholmen i Stockholm. I det nyligen åt söder expanderade Storsverige framstod örlogsbasen i Stockholm som något perifer. Den låg långt upp i norr och inbäddad i en djup skärgård. Det förhållandevis nordliga klimatet gjorde 
dessutom att den danska flottan alltid var snabbare ut på Östersjön om våren.

Redan i april 1676 hade den danske amiralen Niels Juel återtagit Gotland med en eskader om fjorton skepp utan att ha mött något egentligt motstånd. Några dagar senare träffade danskarna på en svensk spaningspatrull bestående av det lilla skeppet Charitas och den bestyckade handelsflöjten Constantia, båda under befäl av Paul Rumpf. De två skeppen jagades av danskarna in i Blekingeskärgården där Charitas togs som pris och Constantia sattes i brand och sänktes av sin egen besättning (för mer information om vraket Constantia se Eriksson 20I4a:I25-I49; Lisberg-Jensen 1972:32-47; Wetterholm I994:I46).

\section{Mellan Rügen och Bornholm}

Under tiden kämpade Creutz med att skrapa ihop skepp, materiel och manskap och fick till stånd en imponerande flotta bestående av 32 skepp, som den 19 maj lämnade Stockholms skärgård. Totalt fanns II 870 man ombord och beväpningen bestod av inte mindre än 2 I72 kanoner. Flottan var indelad i fyra eskadrar: eskadern med kronan i flaggan på Kronan, varifrån Lorentz Creutz förde befälet; eskadern med den gula flaggan på Svärdet, som fördes av den erfarne viceamiralen Claes Uggla; eskadern med den blå flaggan på skeppet Nyckeln, där amiral Johan Bär förde befäl och i vilken även Riksäpplet ingick samt eskadern med den svenska flaggan på Victoria, där amiral Johan Bergenstierna förde befäl (Lundgren I997:85; 200I; Tornqvist I788:I44-I 45).

Flottan begav sig söderut i Östersjön för att leta rätt på den danska och komma till ett avgörande. Strax norr om Öland avled amiral Bergenstierna och skeppen i hans eskader portionerades ut i de tre återstående avdelningarna. Den 25 maj mötte svenskarna de danska skeppen mellan Bornholm och Rügen. Den numerärt överlägsna svenska flottan hade här chansen att få till stånd ett förkrossande slag mot den danska. Men tillfället gled dem ur händerna.

Vad som egentligen hände vid denna sammandrabbning har många försökt att utreda (se t.ex. Johansson 1985; Lundgren 1997; 200I; Hammar 2007; Einarsson 2016:70-86). De flesta tycks dock vara överens om att det var bristande erfarenhet som gjorde att de danska kunde komma undan. Det saknades samförstånd kring signalering och flottans formering. De svenska skeppen seglade för långt från 
motståndaren och för högt i vind och var för splittrade för att kunna utdela verkligt förödande kanonsalvor mot fienden.

Utgången av slaget var minst sagt nedslående. Tre mindre fartyg förlorades till danskarna och ett okänt antal människor fick sätta livet till. De danska skeppen lyckades segla undan mot Öresund och svenskarna kunde inte följa efter eftersom de var ovana vid farvattnen, där åtskilliga sandrevlar förrädiskt hotade under ytan. Tillfället gick förlorat och de svenska skeppen nödgades släppa iväg fienden för att därefter ankra upp utanför Trelleborg.

Från ett kyrktorn i Ystad hade Karl XI med egna ögon bevittnat händelseförloppet med hjälp av "Dahlbergs perspective", en tubkikare (Tornqvist I788:I48). Han var djupt besviken på den bristande "forcen" i attackerna och spårade feghet på alla håll (Lundgren 1997:92). Kungen hade själv sett hur de danska skeppen sluppit ur den fumlande svenska flottans grepp.

Huvudansvaret för nederlaget ansågs ligga på den blå eskadern som löd under Johan Bärs befäl. I eskadern ingick även Riksäpplet med viceamiralen Christer Boije samt majoren Johan Klerk ombord på Saturnus. De tre anklagades för att ha försummat sin plikt och inte tagit strid mot fienden. Bär fick behålla sitt befäl på gamla meriter. Han skulle så småningom ställas under förhör men blev till att börja med tillfälligt benådad med kravet att han vid nästa slag skulle vara tapprare (Lundgren 1997:89; se även genomgång hos Hammar 2007).

På Riksäpplet, som var Boijes skepp, togs flaggan ner och han miste befälet. Han fick dock stanna kvar ombord och segla med hem till Stockholm. Klerk fick i likhet med Bär behålla sitt befäl, förmodligen helt enkelt därför att det rådde brist på officerare (Hammar 2007:I8). På sätt och vis är det redan här som domen faller över Riksäpplet, ett skepp vars befälhavare misstänkliggjorts och pekats ut som en odugling och fegis. I Boijes ställe blev kommendör Olof Borg befälhavare.

\section{Kronan exploderar}

Medan svenska flottan låg i Trelleborg fick den danska förstärkning av nio skepp från Nederländerna under befäl av den berömde sjöhjälten Cornelis Tromp. Han hissade befälsteckningen ombord på det danska skeppet Christianus V och därefter gick den förenade flottan ut mot den svenska med förnyad kraft. Svenskarna höll rådslag och fann det klokast att röra sig norröver för att i händelse av strid ha möjlighet att 
retirera in i skärgården. Målet var att inte börja slåss förrän de passerat Ölands norra udde. Den svenska flottan seglade nu upp längs kusten tätt följda av den fientliga flottan som knappade in på dem.

Vad som egentligen föranledde katastrofen i höjd med södra Öland är oklart. Förmodligen var det så att besättningen på Svärdet avlossade ett skott, vilket var ett brukligt sätt att fråga amiralen om man skulle vända och samla sig för strid. Ombord på Kronan tolkade riksamiralen Creutz signalen som att det var dags att vända och gå mot fienden, varpå han signalerade åt hela flottan att vända. Enligt tygmästaren Gyllenspak, som överlevde katastrofen, förbereddes inte vändningen ordentligt. I den kraftiga vinden hade seglen behövt revas: "om vi vänder i detta hårda väder, med detta ranka skepp, så sker oss visst en olycka" (Bechstadius I724:136).

Kronan krängde så kraftigt att vatten strömmade in genom de öppna kanonportarna på undre batteridäck. Ytterligare kraftiga vindbyar tryckte slutligen helt ner det gigantiska skeppet på sidan. När Kronan låg platt med masterna i vattnet exploderade krutdurken och skeppet gick snart till botten. Endast ett fătal av de 850 personer som fanns ombord överlevde explosionen och låg och flöt bland vrakspillrorna. Bland de stupade fanns riksamiralen Lorentz Creutz.

\section{Svärdet brinner}

Viceamiral Claes Uggla ombord på Svärdet blev nu flottans högsta befäl (fig. 2.2). Medan Kronan kantrade var den övriga flottan på väg att vända på Creutz order. I förvirringen som följde på amiralsskeppets plötsliga explosion bröt svenskarna sina formeringar och spreds över ett stort område. Åtskilliga oöverlagda manövrar och olyckor följde. Bland annat förlorade Riksäpplet sitt stormärssegel och hade svårt att manövrera.

I luckorna mellan de svenska skeppen trängde fienden in och snart var Svärdet omringat. Slaget gick därmed in i en ny fas som också kommit att bli en av de mest omskrivna striderna i den svenska flottans historia. Det har ibland hävdats att amiral Uggla som ensam befälhavare valde att ta strid mot fienden. I själva verket var det flera svenska fartyg som försökte nå fram och understödja, bland andra Neptunus, Jernvågen och Hieronymus. Fienden hade dock kommit för nära det svenska viceamiralskeppet (se även Grandien I985:I39-I4O; Hammar 2007:15-16). 


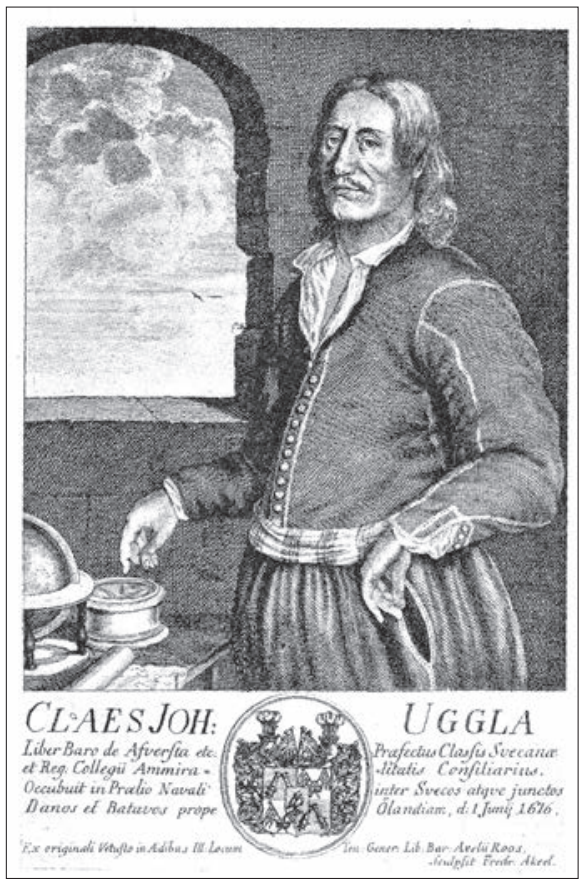

Fig. 2.2. Gravyr efter målning av amiral Claes Uggla, en person som nått hjältestatus i historieböckerna. Efter Kuylenstierna 1908:126.

Bland de skepp som nu avfyrade bredsida på bredsida mot Svärdet återfanns Churprinsen, med den danske amiralen Niels Juel ombord, samt det redan nämnda skeppet Christian $V$ med Cornelis Tromp som befäl. Uppgifterna kring slaget är motstridiga. Tromp menar att han lyckades skjuta Svärdets stormast överbord (Grandien 1985:I40), medan andra källor hävdar att masten bröts i samband med att Svärdet tvingades väja för det fortfarande flytande Kronan (se t.ex. Kuylenstierna I880:I25-I32; Tornqvist I788:I33).

Det finns också motstridiga uppgifter om huruvida Uggla verkligen strök flagg och bad om kvarter. Den holländske amiralen menar det senare i sin skriftliga rapport till danske kungen. Den rutinerade holländske amiralen ansåg att det var Uggla välförtjänt att få det "såväl för sin tapperhet som för sitt osedvanliga försvar" (Grandin 1985:I40). Tromp sände över en slup för att hämta Uggla då en holländsk brännare dök upp och lade till mot Svärdet. 
Brännare var skepp som fyllts med allehanda eldfängt material såsom tjära, beck och annat. Brännaren seglades fram, hakades fast på fienden och antändes. När brännaren var fastgjord på sitt offer lämnade de ombordvarande fartyget genom en särskild dörr, vanligtvis placerad i skeppets akter (för en översikt se Kirsch 2009). Sedan den holländska brännaren D'Hoen (hönan) lagt till mot Svärdets akter stod skeppet snart i ljusan låga.

Bland de svenska vittnesmålen från striden saknas helt uppgifter om att Uggla skulle ha strukit flagg och givit upp. Tornqvist menar i sin sjökrigshistoria författad drygt I 20 år efter slaget att "hvad utrikes skribenter anföra" om att Uggla skulle ha strukit flagg och bett om kvarter var helt felaktigt (Tornqvist I788:I34). De svenska utsagorna ger inte några klara besked. Enligt vittnesmål från överlevande ville Uggla "icke lämna ett så kapitalt skepp med så stora stycken (kanoner) i fiendens händer" (ibid.). Det behöver knappast kommenteras att de svenska uppgifterna om att flaggan satt kvar är lika tendensiösa som Tromps om att den togs ner.

Så småningom nådde elden Svärdets krutförråd och akterskeppet kom därmed att i det närmaste utraderas. Nedtyngt av de tunga kanonerna sögs det stora skrovet snart ner i djupet och med följde omkring 600 personer inklusive Claes Uggla. De kvarvarande svenska krigarna ansåg det lönlöst att understödja sedan brännaren lagt till mot Svärdet. De flydde norrut.

\section{Riksäpplet sjunker}

En del svenska skepp togs som priser av fienden, andra sattes avsiktligt på grund, medan återstoden seglade norrut in i skärgården. På kvällen den 2 juni ankrade Riksäpplet och de andra skeppen vid Dalarö och dagen därpå anlände Gustav Otto Stenbock, som trots sitt misslyckande året innan igen hade blivit riksamiral efter Creutz död. Fientliga skepp kryssade på det öppna havet utanför och i oron för en attack förstärktes skansen på ön Kycklingarna vid Dalarö med kanoner från skeppen (Lundgren 1997:87).

På riksamiralens order förflyttades Riksäpplet och skeppet Jupiter till Dalarö skans utanför den sydöstra stranden för att ta skydd under den massiva gråstensfästningens kanoner. Skeppet förlades med akterstäven mot land förtöjd med trossar i de kraftiga moringarna av 
järn som fortfarande syns väl vid muren. I fören fälldes ett ankare (Stackell I929:22).

Den 5 juni kom en skärgårdsbo ombord på Riksäpplet och berättade att fienden befann sig två mil därifrån. Befälhavaren Olof Borg, som övertagit kommandot ombord på Riksäpplet efter att Boije avsatts, beslöt sig för att själv ge sig ut och rekognosera och övertyga sig om uppgiftens riktighet. Under tiden hade vädret försämrats och en svår storm blåst upp. Innan Borg lämnade skeppet befallde han underofficerarna att ro ut med ytterligare ett ankare.

Christer Boije hade alltså fråntagits befälet redan nere vid Trelleborg, men fick ändå segla med upp till Stockholm. Sedan kommendör Borg gett sig iväg på sin rekognoseringsexpedition förklarade skepparen för Boije att de inte kunde få ut ett extra ankare i den starka stormen. Boije upprepade Borgs order att ytterligare ett ankare skulle läggas ut för att skeppet skulle ligga säkert. Skepparen tycks emellertid helt ha ignorerat befallningen och Boije försökte då få manskapet att "minska stänger och rår", vilket innebär att så mycket som möjligt av riggen demonteras för att minska vindfånget. Men enligt hans efterlämnade journal struntade de blankt $\mathrm{i}$ hans order sedan han förlorat sin befattning och ersatts av kommendör Borg (Stackell 1929:22).

Det var en gravt förolämpad Christer Boije som lämnade de tjurskalliga sjömännen och gick ner under däck. Helt ensam i den hårda tillvaron ombord på Riksäpplet var nu inte den stukade före detta amiralen. Det finns nämligen en intressant uppgift om att Boije, sedan han lämnat däcket, klev in i ett rum där även hans dotter befann sig. Medan stormen tilltog satte sig Boije ner för att skriva "en supplik till kollegio". Han blev dock snart avbruten av sin dotter som med näsan mot ett fönster utbrast "far, vi komma nu så nära till det andra skeppet" (Lundgren 200I:229). Boije sprang ut på däcket, såg faran, men kunde inget göra. Riksäpplet hade släppt sina förtöjningar och kommit på drift.

Förste kaptenen Elias Johansson Garff var sjuk, varför det yttersta ansvaret för skeppet vilade på kapten Ewert Haas. På inrådan av styrmannen hade Haas givit order om att man skulle vinda något på ankarlinan för att skeppet inte skulle utgöra ett så stort vindfång. Under arbetet sprang plötsligt akterlinorna av och skeppet kom loss. Det enda ankaret var långt ifrån tillräckligt för att bromsa och stoppa det stora skeppet med alla dess tunga kanoner ombord. Riksäpplets sista resa gick omkring 630 meter i närapå rakt ostlig riktning och slutade med att 
skrovet slog hårt mot en granithäll. Vattnet forsade in i krutkammaren och trots en febril aktivitet vid pumparna och langande med pytsar började skeppet sjunka med fören först och med en tilltagande slagsida åt styrbord. Man försökte motverka detta genom att rulla över några av kanonerna på babordssidan. Men det var hopplöst.

När vattnet nådde de understa kanonportarna kantrade skeppet från klabben och sjönk. En äsping från skeppet Nyckeln som kommit till hjälp för att bärga seglen drogs med ner i djupet (Stackell I929:23). Större delen av besättningen ska ha räddat sig. Kapten Haas och styrmannen sattes genast i arrest. Ett halvt år senare blev Haas frigiven, men avskedades från tjänsten (se t.ex. Zettersten 1903:482).

\section{Kommissionen}

En kommission tillsattes för att utreda vem som bar ansvaret för nederlaget vid slagen mellan Rügen och Bornholm samt vid Ölands södra udde. Till grund för dess arbete låg den sammanfattning av anklagelserna som gjorts av sekreteraren Erik Lovisin. Det är kanske föga förvånande att vittnesmålen om vad som verkligen hände inte är alltigenom samstämmiga. Oredan och förvirringen under stridens hetta, liksom det faktum att många befäl stupade, har bidragit till att det är svårt att reda ut det nesliga nederlagets egentliga orsaker.

Anklagelserna riktades främst mot officerarna i Bärs eskader, de som redan i Trelleborg - det vill säga före Kronans och Svärdets förlisningar - hade anklagats för feghet. Som Axel Zettersten formulerar saken i sin Svenska flottans historia ansågs Riksäpplets befälhavare, Christer Boije, vara "den mest felaktige" (Zettersten 1903:476). I kommissionen menade Boije till sitt försvar, att det var svårt att nå fram till fienden med Riksäpplet eftersom andra svenska fartyg låg i vägen. Han ansåg att han hade kämpat som en ärlig man, samt att hans skepp träffats av inte mindre än 76 skott (Lundgren 200I:2I). Det var hur som helst svårt att bevisa hur frekvent Riksäpplets skrov hade genomborrats av fiendens eld, eftersom skeppet låg på havets botten vid tidpunkten för rannsakningen. Medan de anklagade amiralerna avlade sina vittnesmål inför kommissionen pågick som bäst arbetet med att bryta sönder skrovet för att komma åt att lyfta kanonerna.

Officerarna Anders Homman och Olof Nortman befann sig ombord på Svärdet, men överlevde katastrofen. Sedan skeppet fattat eld, exploderat och gått till botten hade de tillsammans med ett femtiotal 
andra räddats ur vågorna och förts till fångenskap i Köpenhamn. Efter frigivningen levererade de graverande vittnesmål om hur deras skepp hade lämnats i sticket för att ensamt utkämpa en hopplös kamp. Deras vittnesmål kan liknas vid fröer som senare slagit rot i en nationalromantisk mylla och blommat ut i en veritabel personkult kring deras stupade amiral Claes Uggla.

Homman och Nortman berättar att sedan Kronan kapsejsat och exploderat - och Uggla axlat ansvaret som flottans högsta chef - sköt Svärdet två skott med bogstyckena på de svenska skeppen Mercurius, Victoria och Lejonet, som signal att de skulle vända och angripa fienden. De båda vittnena berättar vad Uggla sagt till sina underofficerare: "Se hur de hundsfottarna löpa och ränna, om någon av eder kommer till Stockholm så tala om hur skälmskt de handlat mot oss" (Lundgren 1997:I08). Hundsfott är I600-talsslang för hundtikens könsorgan och kanske det grövsta man kunde förolämpa en "ärlig man” med. De båda vittnena menar vidare att Uggla förmanat dem "att kämpa manligen. Det är bättre att ärligen dö för sin fiende än att bliva hängd i Stockholm" (ibid.).

Uggla hade förmanat Solen och de andra skeppen som seglade förbi att stanna hos honom och fäkta som ärliga karlar, men "de löpte efter varandra, den ene hit, den andre dit som hönsen kring gården" (ibid.). De två frigivna fångarna berättar också att Bärs eskader, där Riksäpplet ingick, seglade nära Öland och försummade att understödja Svärdet i den sista striden.

Ingen blev dock nämnd med namn och kanske var det svårt att reda ut vilka skepp som så slemt övergivit Svärdet, i synnerhet som de alla "seglade hit och dit". Men "om Uggla varit i livet tror jag nog att några hade blivit namngivna och en ny galge hade blivit uppsatt $\mathrm{i}$ Stockholm", menade Nortman (Lundgren 1997:I I I).

Kommissionens arbete fortgick oerhört långsamt och det var svårt att få fram bevis och någon verklig syndabock. Samtidigt rasade kriget och det var snart dags för ett nytt sjötåg. Claes Rålamb, som ingick i kommissionen, insåg det problematiska $\mathrm{i}$ att officerarna gick med anklagelserna hängande över sig. De blir "tröga och kan inte göra Hans Majestät en riktig tjänst", påpekade han (Lundgren 1997:I I6). Under våren och sommaren $\mathrm{I} 677$ friades de en efter en.

Men även om de friats från anklagelserna så var deras rykte ordentligt skamfilat. Att bli misstänkliggjord för feghet var en skam som var svår att skaka av sig. Slaget vid Öland stod nära land och iakttogs av 
många ögonvittnen. Ryktesspridningen om nederlaget var snart igång och spreds som en löpeld. En som fick sin beskärda del av denna förbannelse var Riksäpplets före detta befälhavare Christer Boije. Han hade svårt att röra sig i det offentliga utan att utsättas för okvädningsord från allmänheten. En månglerska, förmodligen en gatuförsäljare, ska ha ropat efter honom: "Haver du tjänt Sverige som en ärlig man? Tvi dig, hundsfott!" (Citat i Lundgren 1997:224).

\section{Sjötåget i krigspropagandan}

Inom rådet betraktades den oroväckande ryktesspridningen tidigt som ett problem. Redan den I 5 juni, det vill säga drygt två veckor efter att slaget ägt rum och endast tio dagar efter Riksäpplets förlisning, skrev de därför ett brev till alla landshövdingar, guvernörer, generalguvernörer, biskopar och superintendenter i syfte att berätta och offentliggöra en officiell version om hur slaget hade gått till.

Att flottan förlorat sina två största skepp med sina respektive amiraler ombord utanför Öland var ett faktum som var svårt att förtiga. Man redogjorde för hur det gått till när Kronan och Svärdet förlist, men i övrigt påstod man att skeppen ankommit till Dalarö eller någon av de andra hamnarna. Två mindre skepp saknades förvisso, men de förmodades ha räddat sig in till någon hamn. Skadan var beklaglig, men dräglig, och fiendens vinst inte så stor.

Sannolikt var det skeppen Järnvågen och Neptunus som omnämns som saknade. De kallas för små skepp, men hade båda besättningar på över 200 man. Som påtalats av historikern Anna Maria Forssberg är det oklart om rådet kände till att dessa skepp hade erövrats av fienden eller om det helt enkelt valde att förtiga denna omständighet. Detsamma gäller förlusterna av mindre fartyg som inte nämns överhuvudtaget. En händelse som rådet säkerligen kände till men som inte nämns alls är Riksäpplets snöpliga förlisning (Forssberg 2005:244).

Det kan givetvis finnas flera orsaker till att förlisningen förtegs i rådets brev. När det skrevs hade skeppet precis gått till botten och kanske hystes ännu förhoppningar om att skeppet skulle gå att bärga i sin helhet. Om så kunde ske skulle flottan kunna skaka av sig hela den pinsamma historien, vända blad och låtsas som om den aldrig hade inträffat. Brevets syfte var att lugna allmogen och förmodligen såg man ingen anledning till att nämna förlusten av Riksäpplet innan det var slutgiltigt konstaterat att skeppet skulle bli kvar på botten. 


\section{Flottans historieskrivning}

En av de tidigaste böckerna om svensk sjökrigshistoria skrevs av den i Karlskrona verksamma prästen Carl Nilsson Bechstadius (I690-I739). Genom att praktisera sitt yrke i den svenska örlogsstaden framför andra fick han med tiden synnerligen god inblick i de svenska sjöofficerarnas genealogi och historia. Den lärde prelaten kompletterade dessa kunskaper med studier i flottans arkiv, vilket mynnade ut i skriften Then adelige, och lärde swenske siö-man. I boken, som trycktes 1734, återkommer sjökriget år I676 i flera olika sammanhang. Bechstadius ägnar förhållandevis stort utrymme åt Kronans undergång, en episod som återberättas utifrån tygmästare Gyllenspaks målande vittnesskildring. Att Kronans förlisning beskrivs så detaljerat har nog främst att göra med Bechstadius tillgång till informanter än att han lät sig imponeras av de inblandades agerande. Den störste hjälten i det olyckliga sjötåget I676 var enligt Bechstadius mening Claes Uggla. Bechstadius berättar att amiralen "[o]mkom i brand på Skeppet Swärdet den I. Junii I676, och fick af Holländska Ammiralen Tromp thet loford, at han giorde alt hwad en tapper Siö-Hiellte någonsin göra kunde" (Bechstadius 1734:105, min kursivering).

Även Anders Homman (I622-I685), som framförde flera av amiral Ugglas sedermera bevingade ord till kommissionen, nämns i Bechstadius verk. Bechstadius beskriver honom som en "Edle och Manhafftig" tjänare (Bechstadius I734:II8). Ordalydelsen är hämtad från epitafiet över Homman som fortfarande kan beskådas framme vid koret i Kalmar domkyrka. Historieskrivning sker inte bara genom text. Monument, minnesdagar och inte minst olika former av konstverk, såsom skulpturer, måleri och just epitafier förmedlar också historia.

På epitafiet över Homman avbildas Svärdets sista strid (fig. 2.3). Det brinnande skeppet ses snett akterifrån och i vattnet klamrar sig delar av besättningen fast vid den avskjutna stormasten. Den av fientliga kulor genomborrade svenska flaggan fladdrar fortfarande på aktern. Tittar man riktigt noga ser man en person som balanserar på babordssidans berghult, en av de kraftigare bordläggningsplankorna utmed vattenlinjen, med en hand på ett eldrör. Med själva syftet med epitafiemåleriet i gott minne förefaller det troligt att det är Homman själv som åsyftas. I bakgrunden syns den holländska brännaren.

Homman dog först I685, hela nio år efter slaget då Svärdet blev lågornas rov. Epitafier över minnesvärda och framstående personer 


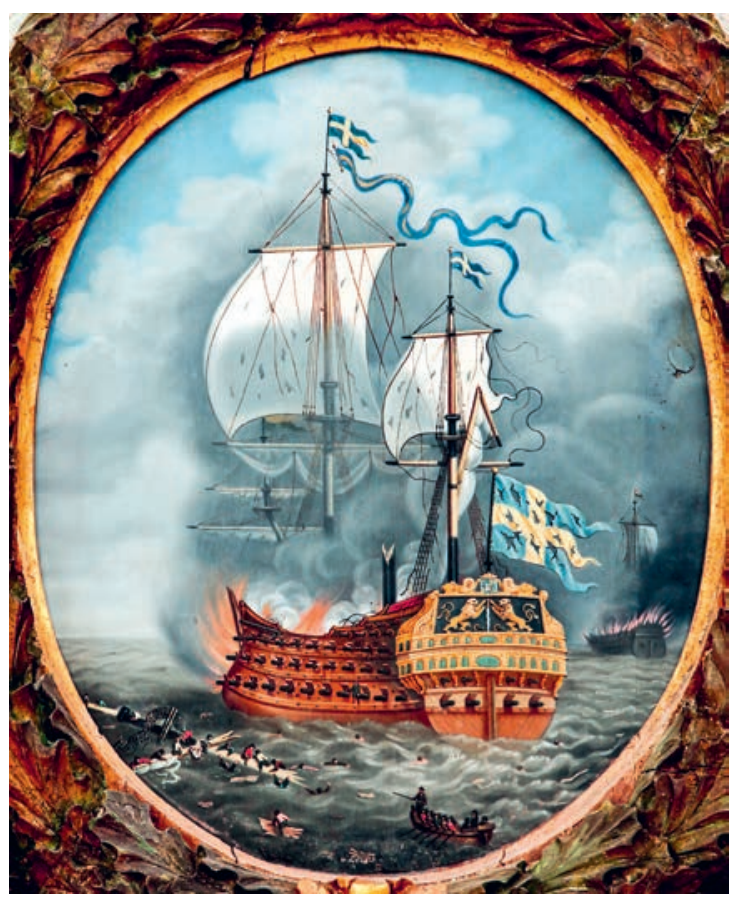

Fig. 2.3. Anders Homman överlevde Svärdets sista strid. Händelsen finns avbildad på hans epitafium som är upphängt i Kalmar domkyrka. I bakgrunden syns den holländska brännaren. Foto: Patrik Höglund.

kunde i vissa fall hängas upp redan under deras levnad. Då sparades helt enkelt ett litet fält där man senare kunde fylla i uppgifter om dödsdatum och liknande (Gillgren 1995:70). Men det finns dock några detaljer i framställningen av skeppet som talar mot att kalmariten Anders Homman själv låtit blicken vila på sitt epitafium medan han suttit och lyssnat på gudstjänsten.

Förvisso stämmer det totala antalet kanoner på det avbildade skeppet förvånansvärt väl överens med vad bestyckningslistorna anger (se diskussion hos Höglund 2013:155-156). Däremot torde arrangemanget med tre fullständiga batteridäck vara felaktigt (Eriksson 20I7b). Likaså hör de dubbla raderna stora fönster på akterspegeln liksom låringsgalleriet som sträcker sig vertikalt över två däcksnivåer snarast hemma i engelskt skeppsbyggeri (se kapitel 7). Skeppet på epitafiet över Homman påminner mer om de skepp som byggdes under I600-talets sista decennier för att ersätta förlusterna från skånska kriget, än om de som 
användes under det. Dessutom invigdes Kalmar domkyrka först I682, vilket också talar för att epitafiet snarare framställdes efter Hommans död än kort efter den återgivna händelsen.

Som konstvetaren Peter Gillgren beskrivit utgör epitafier de kanske tydligaste exemplen på hur den personliga fromheten manifesteradess i offentlig miljö under stormaktstiden. De fungerade som äreminnen och beskriver individens möten med det gudomliga (Gillgren 1995). Epitafiet över Homman är den enda bilden av Svärdet som har koppling till en som verkligen var med om händelserna 1676 .

Bechstadius är i sin sjökrigshistoria även smärtsamt medveten om de mindre ärofulla episoderna i I676 års sjökrig. Vid sidan av dramatiken kring Kronan och Svärdet berättar han den dråpliga berättelsen om hur "thet sköna Skepp, Äplet som förde 8o. Canoner. Ithy, at igenom Capiteinens oförsichtighet och oförståndiga Commendo, thet råkade uppo grund, uti Dalaröön och sanck" (Bechstadius I734:I39). Den noggranne Bechstadius redovisar också att krönikören Eberhard Werner Happelius (I647-I690) helt felaktigt påstått att "Capitainen fick therföre i repet til löna, och blef uphängd i en galga icke långt ther ifrån”. Bechstadius är tydlig med att han inte vill uttala sig om ifall Haas förtjänade en sådan behandling, men berättar i enlighet med vad som verkligen hände att Haas blev frigiven.

Krönikan där Haas påstås ha fått "repet til löna" trycktes samma år som händelsen utspelat sig, varför utsagan ska betraktas som ett uttryck för den lynchartade stämning och de hårda domar som allmänheten gav dem som inte lyckades tjäna fosterlandet på ett framgångsrikt sätt. Krönikörens överdrift rörande bestraffningen, liksom månglerskans glåpord efter Boije, uttrycker allmänhetens dom. Den i sammanhanget mycket balanserade Bechstadius menar dock att Haas knappast ska lastas för olyckan med Riksäpplet. Haas var inte alls någon sjöman utan tjänade sitt uppehälle genom att vara vinskänk i Stockholm, "men nu uti thet nybegynta krig, igenom gunst och wänner, mycket oförskyldt, blefwit Skeps-Capitein" (Bechstadius I734:I39). Bechstadius ansåg att den som satt honom till kapten borde betala för kungens skepp.

Ewert Haas hade sedan 1664 hade kungligt privilegium att importera ostron (Lagerwall I869:I59). I ett brev till Magnus Gabriel De la Gardie kommenterar Peter Chambers (16IO-I678) det hela: "Stackars Evert Haas, han hade just vakt när skeppet Äpplet kom till den olyckan. Han lär stå sig illa. Han skulle ha blivit kvar vid handel, men tids 


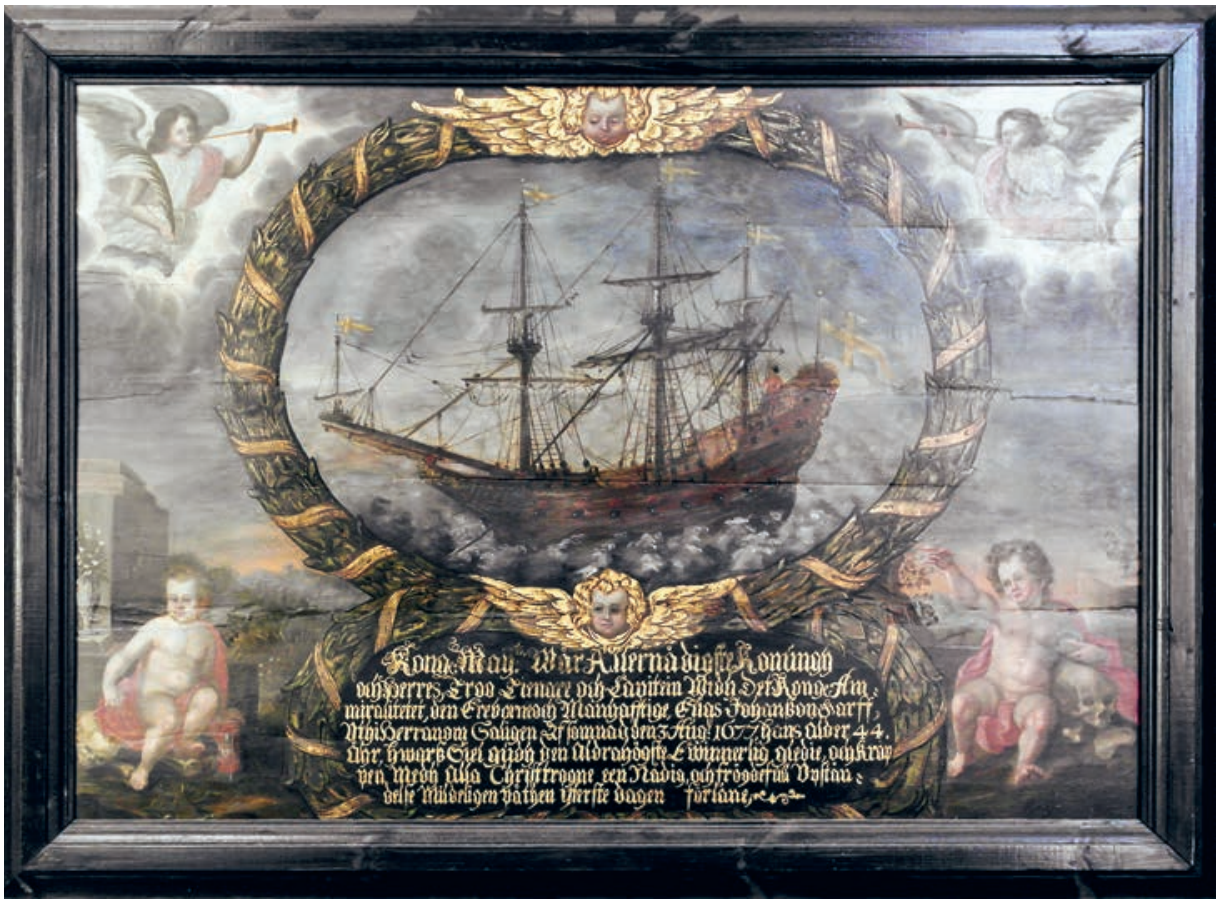

Fig. 2.4. Kapten Elias Johansson Garff var kapten på Riksäpplet men låg sjuk då skeppet förliste. På epitafiet över honom i Hedvig Eleonora kyrka i Stockholm visas hur skeppet draggar och släpar ankaret över botten. Även om målningen kan anses avbilda händelsen korrekt så är skeppet som återges betydligt mindre än det verkliga. Foto: Niklas Eriksson.

nog blev han kapten" (citat i Lundgren 1997:223). Han var således en åtminstone i vissa kretsar respekterad person, även om han kommit att framstå som en hopplös sjökrigare. Beträffande amiral Christer Boije konstaterar Bechstadius kort att han blivit "dimmiterad uthur tiensten" (Bechstadius I788:I08).

Haas hade övertagit ansvaret för Riksäpplet från kapten Elias Johansson Garff som var sjuk vid tidpunkten för förlisningen. Garff lastades aldrig för Riksäpplets ömkliga förlisning. Året efter händelsen dog han. Det skepp som målats på epitafiet över honom anses ibland avbilda Riksäpplet (Börjesson 1942:24I; Åberg 1985:73; Soop 2007:134). Skeppet har målats utan segel mot en grå himmel och med en sträckt ankarkabel som försvinner ner i den upprörda sjön. Motivet kan på tämligen goda grunder anses avbilda Riksäpplets sista färd, då skeppet med 
bogankaret släpande över botten kom drivande från ankringsplatsen mot granithällen. Men även om epitafiets motiv avbildar händelsen så är det inte ett porträttlikt skepp som målats. Det är betydligt mindre än Riksäpplet och har endast ett batteridäck (fig. 2.4).

Epitafiet över Johansson Garff återfinns i Hedvig Eleonora kyrka i Stockholm. Under I60o-talet var den amiralitetskyrka i Stockholm och åtskilliga sjöofficerare finns begravda där. Det avbildade skeppet tycks ha varit ett standardmotiv på minnestavlor över flottans män. Endast några meter från nyss nämnda epitafium hänger ett liknande med ett närapå identiskt skepp.

I likhet med epitafiet över Homman så rymmer epitafiet över Garff en avbildning av honom själv. Han står på akterdäcket med ett svärd i högra handen och den vänstra handen på höften. Det kan tyckas lite märkligt att Garff framställdes inför Gud och eftervärlden tillsammans med Riksäpplet och i synnerhet det olyckliga missöde som ledde till skeppets förlisning. Men tittar man en gång till på målningen så ser man att han minsann gjort skäl för äran. Om detta vittnar den på flera ställen genomskjutna tretungade flaggan i skeppets akter samt texten som berättar om den "Ereborne och Manhaftige" Garff.

Drygt 50 år efter att Bechstadius bok tryckts, utkom Carl Gustav Tornqvist med Utkast till Swenska Flottans Sjö-tåg i två band (1788). Som titeln antyder är boken en redogörelse för flottans operationer år för år. Framställningen av Uggla, Creutz, Boije och Haas och förlusterna av Kronan, Svärdet och Riksäpplet är mycket saklig och utförlig. Utifrån Bechstadius har Tornqvist skissat upp ett vederhäftigt ramverk av händelser, personer, skepp och sjöslag som passerar revy men alltjämt är lätt att ta till sig. Att Tornqvist använt sig av Bechstadius framkommer av flera referenser. Under I800-talet och det tidiga I900-talet återgavs Tornqvists framställning i många böcker om svenska flottans historia. Men inte rakt av och inte ordagrant, utan den kom att dekoreras med allt fler romantiserande krusiduller.

En som var bekant med svenska flottan och flottans historia var marinmålaren Johan Tietrich Schoultz (I754-I807). Han var själv sjömilitär och deltog i Gustav III:s krig mot Ryssland I788-I790. Mest känd är han just för sina målande skildringar av detta krig, som han producerade i stor mängd. Vid en inventering konstaterades ett åttiotal kända dukar av hans hand, varav 78 avbildade stridigheter han själv bevittnat. Men i hans produktion återfinns även andra berömda motiv från den del av svenska flottans historia som högaktats av flot- 


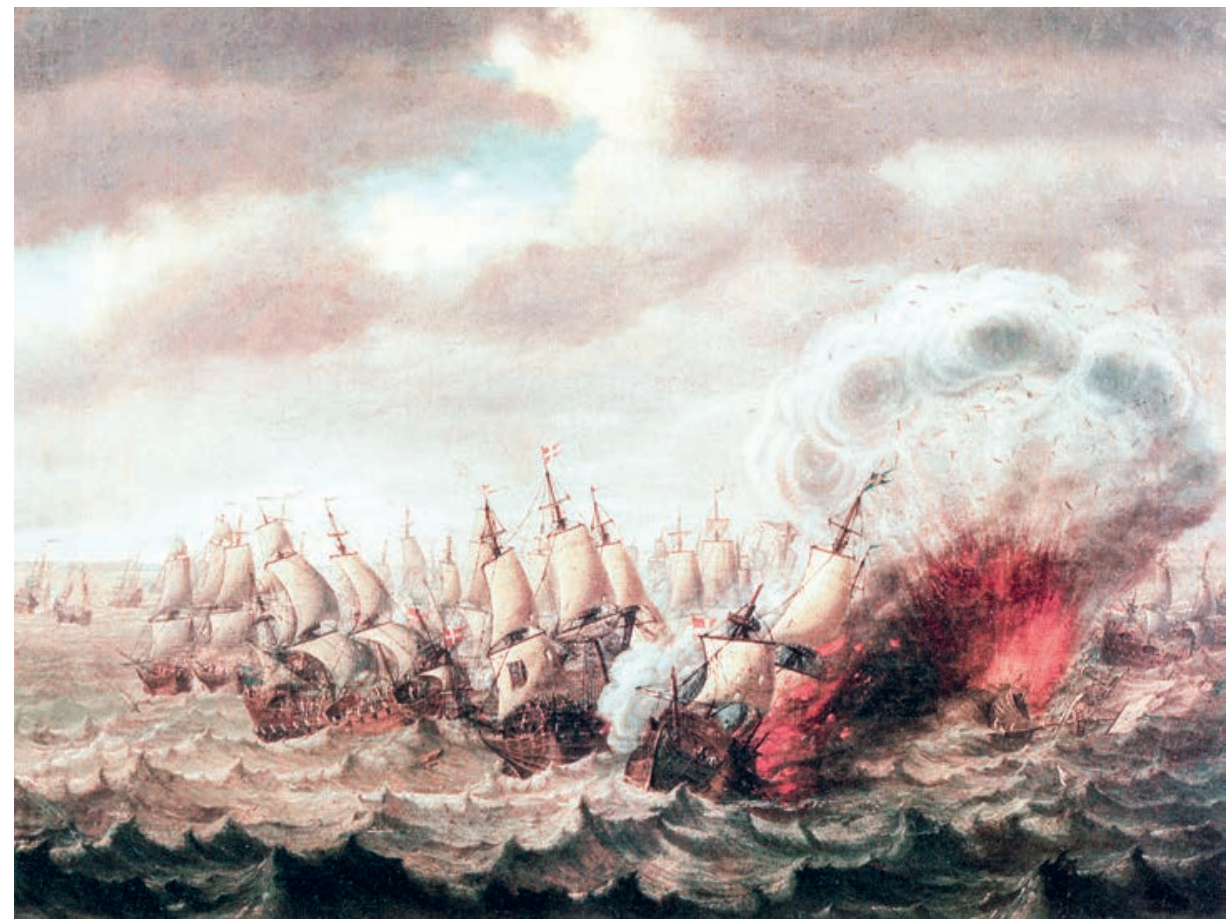

Fig. 2.5. Johan Tietrich Schoultz målade denna tavla av slaget vid Öland redan under 1770-talet. Efter Brorsson 2004:170-171.

tans män, såsom skeppet Ölands strid mot engelsmännen I704 samt sjöslaget vid Femern I644 (jfr Unger I932:I-I6).

En målning som kallats "Sjöslag mellan svenska och danska skepp" (Brorsson 2004:I70-I7I) torde utgöra en tidig svensk framställning av slaget vid Öland (fig. 2.5). Intressant nog är den målad från närapå motsatt perspektiv jämfört med Claus Møinichens tavla (jfr fig. I.I). Det övertända skeppet Svärdet utgör på Schoultz tavla huvudmotivet och återfinns i förgrunden. Det brinnande hjälteskeppet avbildas snett förifrån och den fortfarande förda blågula flaggan avtecknar sig mot ett blåsvart rökmoln som stiger bakom skeppet. Rökmolnet härrör från den briserade krutdurken ombord på Kronan. Riksamiralens skepp skymtar fram bakom Svärdet och ligger helt på sida i bakgrunden. Schoultz framställning visualiserar på det här viset den version av slaget vid Öland som dominerade under I8oo-talet. Då spelade nämligen i stor utsträckning Uggla och Svärdet huvudrollerna. 


\section{Att fånga en Uggla}

Ett tillägg till legenden om Svärdets sista strid som tycks ha uppstått ur tomma intet någon gång under I800-talet, är en ordväxling mellan Uggla och den nederländske amiralen Cornelis Tromp. Den ska ha ägt rum mitt i stridens hetta och bygger på att Tromp skulle ha ansett att Uggla förtjänade aktning och därför sänt över en båt för att hämta honom. I Gustav Henrik Melins Lärobok i fäderneslandets historia från I845 kan vi läsa: "Tromp, som beundrade Ugglas tapperhet, uppmanade honom att gifva sig. Uggla svarade leende: 'när såg man en uggla någonsin låta fånga sig på ljusan dagen?’” (Melin I845:282) Den tappre sjöhjälten kastade sig därefter i vågorna. Om Melin själv knåpat ihop den lilla spetsfundigheten eller om han snappat upp den på annat håll är svårt att uttala sig om. Sägnen har dock kommit att omhuldas och reproduceras av många författare (se t.ex. af Trolle I868:92; Kuylenstierna 1908:I3I; Unger 1942:464). Den förekommer till och med i det i övrigt så vederhäftiga bokverket Svenska flottans historia.

Ordväxlingen utbroderades så småningom med en liknande käckhet från motståndaren. Fienden ska ha ropat "Nu kan Ugglan ge sig med detsamma annars ska vi klippa vingarna" (Grandin 1982:I40-I4I) innan Uggla ropar sitt legendariska svar om att ugglan inte kan fångas på ljusan dagen.

Böckerna om den svenska flottan och dess historia från I700-talet och en bit in på I900-talet skrevs i uppbyggligt syfte (se diskussion hos Cederlund 1997). Creutz målas mer och mer upp som en oduglig krigare, vars inkompetens orsakade Kronan-katastrofen och det allmänna kaos som följde. Åsikten kommer bland annat till uttryck i Henrik af Trolles (I829-I886) Svenska Flottan, dess minnen och öden från äldre tider intill våra dagar. Trolle var sekundlöjtnant vid flottan och sedermera journalist och framför tämligen bestämda uppfattningar om vilka som ska lastas för flottans nederlag (af Trolle ı868:92-93):

Med Uggla till högste befälhavare hade striden troligtvis fått en för svenskarne lyckligare utgång. När man bland annat hufvudlöst äfven besinnar, att en källarmästare Haas i Stockholm blifvit utsedd till befälhafvare på skeppet Äpplet, som af brist på nödig uppmärksamhet efter hemkomsten råkade i drift, stötte och sjönk i Dalarö hamn, så må man förundra sig öfver att ej större delen af svenska flottan gick förlorad. 
En som definitivt tog del av den här nationalromantiskt färgade historievurmen var prins Oscar Fredrik (1829-1907), som gjorde karriär inom flottan för att slutligen nå viceamirals grad (Oscar II, urn:sbl:78I2, Svenskt biografiskt lexikon (art. av Torgny Nevéus), hämtad 20I7-03-29). Örlogskarriären fick dock läggas på hyllan sedan tronföljden, genom hans bröders frånfälle, gjort honom till kung över Sverige och Norge under namnet Oscar II. Han var dock inte sen att påpeka att "ett helt ungdomslif, förflutit under förtroligt umgänge med den svenske sjö-officeraren" (Oscar Fredrik I 858:3). Kung Oscar har efterlämnat ett av de mest fascinerande uttrycken för hjältevurmen kring Claes Uggla genom dikten "Claes Uggla på Svärdet I676". Den ingår i diktsamlingen Ur svenska flottans minnen som gavs ut för första gången 1858 .

I tolv verser återger den blivande monarken huvuddragen i slaget vid Öland, varvid han givetvis lovsjunger Ugglas mod och pliktkänsla. Den blivande kung Oscar frammanar bilden av en närmast övermänsklig ståndaktighet hos den svenske viceamiralen som efter att "Cronan [...] som sam lik en konung på hafvet" exploderat, Svärdet fattat eld och besättningen förtvivlat kastat sig i havet, stannade kvar ombord (Oscar Fredrik I858:19):
Clas Uggla den brådskan ej led.
Han stod "som i djupaste fred";
Stod qvar, tills han ensam sig finner
På däck, som i lågor försvinner.
Stolt synar han ännu en gång
Sitt sjunkande skepp. Med ett språng
Se'n modigt han störtar i vågen
Och qväder med döden $\mathrm{i}$ hågen,
Men blicken på brinnande flagg.

Den blivande kungen lutade sig således mot den i svenska skildringar ofta framförda versionen att "Uggla sjelf var den siste, som kastade sig i sjön, och såg, flytande på ett trästycke, innan han drunknade, sin flagga brinna upp utan att strykas" (Melin I845:282). Hur det nu var med den saken, om flaggan satt kvar eller om den togs ner, som ju Tromp påstår, är ovisst.

Ett återkommande sätt för olika mariner att hedra sina hjältar är och har varit att döpa sina fartyg efter dem. I England finns åtskilliga 
Corpedkryssaren Claes Uggla under forcering.

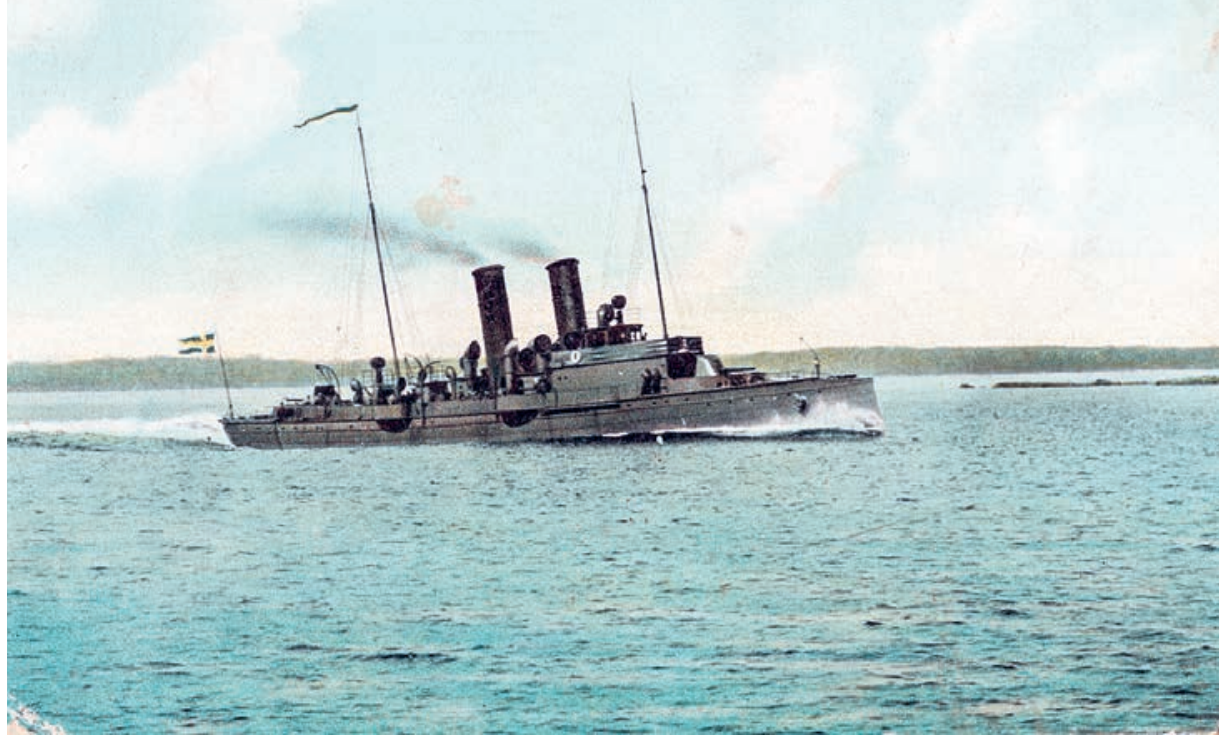

Fig. 2.6. Flottan har uppkallat fartyg efter amiral Uggla för att hylla honom. På det kolorerade vykortet ses torpedkryssaren Claes Uggla "under forcering". Fartyget byggdes 1899, strandade 1917 och bärgades av bärgningsfirman Olschanski, innan bolaget gav sig i kast med Riksäpplet. Författarens samling.

skepp uppkallade efter Nelson och i Nederländerna heter de De Ruyter. Att Uggla var ett föredöme illustreras inte minst av att flera skepp och båtar döpts efter hjälten för att påminna om hans bedrifter (fig. 2.6). För " [s]å länge en svensk flotta existerar, är Claes Ugglas namn förenadt med densamma, och stoltare namn kan svårligen ett under blågula örlogsflaggan gående fartyg bära” (Kuylenstierna 1908:I32). Mig veterligen har inget fartyg kommit att uppkallas efter vare sig Creutz, Boije, Bär eller Borg - amiralerna som med sina eftermälen knappast varit föredömen för flottans män.

Berättelsen om de olika amiralerna och deras skepp, med den arketypiska rollfördelningen, spreds dock långt utanför den till synes snäva kretsen av historiskt intresserade sjöofficerare. Genom de historieverk som började ges ut under I80o-talet kom berättelsen att leta sig in i många bokbildade hem. Anders Fryksells Berättelser ur den svenska historien gavs ut i hela 49 delar mellan I828 och I 893 och intar en särställning bland I80o-talets alla historieromantiserande verk. Fryksell 
anses ha inspirerat storheter som Zacharias Topelius, Victor Rydberg, Verner von Heidenstam, Carl Snoilsky, August Strindberg med flera (jfr Hägg 1999:298). Sjötåget 1676 och slaget vid Öland avhandlas tämligen ingående. Fryksell, som i stor utsträckning anses fokusera på att biografera de historiska personerna, målar upp Lorentz Creutz som en kolerisk, hårdför och inkompetent person, i bjärt kontrast till den duglige sjökrigaren Uggla som "i vågor eller lågor [gick] hjeltedöden till mötes" (Fryksell I848:84-92, citat: 9I). Fryksell framställer i allt väsentligt de båda amiralernas karaktärer som motsatta ytterligheter.

Det enda som i Fryksells (I848:92) skildring anspelar på Christer Boije och Riksäpplet är: "På hemvägen förliste ett skepp utanför Westervik och ett annat genom sjökaptenens oskicklighet i Dalarö hamn.” De förtjänade således inte ens att nämnas vid namn. I övrigt är framställningen av slaget ingående.

Det verk som på sätt och vis kan tyckas utgöra en uppföljare eller ersättare för Fryksells är Carl Grimbergs Svenska folkets underbara öden. Medan Fryksell fătt rykte om sig att vara såväl kungakritisk som pacifistisk har Grimberg hållits för raka motsatsen (jfr Hägg I999:298). I Sveriges riksdag kritiserade socialdemokraternas ledare Hjalmar Branting Grimbergs läroböcker för att vara skrivna i en "nationalistisk och krigsförhärligande anda" (Torbacke 1993; Matz 2001:42-45; Aronsson 2004:I28). Grimbergs framställning av slaget vid Öland är förvånansvärt kortfattad men innehåller ändå de till synes viktigaste komponenterna, det vill säga påståendena att Lorentz Creutz bristande erfarenhet och kompetens ledde till Kronans undergång samt att Uggla spelade förstafiolen (Grimberg 1922:158):

När Stora Kronan kantrade, måste han [Uggla alltså] vända undan vind för att ej kollidera med amiralskeppet. Men vid denna farliga manöver bräcktes stormasten på hans fartyg, och skeppet vräktes på sidan samt blev liggande redlöst. "Kapa stormasten!” ljöd Ugglas befallning - ty ge sig skulle han ej. Yxorna svängdes med förtvivlans kraft, stormasten gick över bord, och skeppet reste sig åter. Sedan besvarade Uggla fiendens eld, tills hans fartyg antändes av en fientlig brännare och med en skarp knall sprang i stycken. Då kastade han sig i sjön och omkom.

Detaljerna kring hur Svärdet förlorade masterna är höljda i dunkel. Den holländske amiralen Tromp menar sig till exempel ha skjutit av 
masterna, medan de flesta svenska författare - i likhet med Grimberg - menar att stormasten bräcktes när Svärdet var nära att kollidera med det fortfarande flytande vraket efter Kronan. I vilket fall som helst så försummar Grimberg att berätta att ytterligare ett regalskepp gick under, strax efter katastrofen utanför Öland.

Författare som Fryksell och Grimberg imponerar onekligen med att som ensamma författare ha skrivit så omfattande verk. Men det finns även tidiga exempel där flera författare engagerats. När det ambitiösa bokverket Sveriges historia från äldsta tid till våra dagar gavs ut I88I ansågs det banbrytande i så måtto att det var det första översiktsverket som skrivits av en samling så välrenommerade forskare och specialhistoriker (jfr Nyström 1930:309). Bland författarna återfinns Oscar Montelius, Hans Hildebrand och andra akademiska tungviktare. När det gäller framställningen av sjötåget 1676 återberättas den vanliga historien om den "i sjömansyrket helt oerfarne Lorens Creutz" och den "hieltemodige amiral Uggla" som var den enda som "höll stånd" (Weibull, Höjer et al. I88I:44I). Riksäpplet och dess befälhavare förtjänade ingen plats i denna framställning heller.

Den påkostade uppföljaren i form av Svenska folket genom tiderna gavs ut av förlaget Allhem på 1930-talet. Enligt förordet i det första bandet eftersträvades att söka "medarbetare av erkänd auktoritet och med självständig forskning bakom sig". Antalet specialister hade avsevärt utökats jämfört med tidigare. Intressant är att avsnittet "Flotta och sjöfart” inte är skrivet av historiker utan av kommendörkapten Georg Hafström och kapten Hjalmar Börjesson. De båda författarnas bakgrund och förkovran i den marinhistoriska litteraturen är inte att ta miste på. Men kanske är det just denna omständighet som ligger till grund för att den inom flottan så ofta återberättade myten om ugglan som inte lät sig fångas smugit sig in i ett standardverk som syftat till att återge Sveriges historia i vidaste bemärkelse (Hafström \& Börjesson 1939:245).

Berättelser om det förflutna kommuniceras dock genom en rad kanaler utöver de historiska standardverken. Från I900-talet finns många exempel på journalister med förmåga att leverera historisk dramatik. En är Alexis Kuylenstierna, medarbetare på Dagens Nyheter och författare till Svenska Bragder och stordåd (1908). Kuylenstierna, som under sin levnad var känd under signaturen "Mustafa" - förmodligen ett minne av hans tid som Asienkorrespondent - har sammanställt en fascinerande samling berättelser. Vid sidan av skildringar om Andrées 
polarfärd, slaget vid Brunkeberg, Gustav Vasas befrielsekrig, tåget över Bält, slaget vid Fraustadt, ett porträtt av Artur Hazelius och en berättelse om hur svenskarna grundade ryska riket, finns ett helt kapitel om "Amiral Klas Johansson Uggla på Svärdet". Där redogör han för hur I676 års fälttåg till sjöss hade fått "ett annat förlopp, om han fört högsta befälet i stället för Lorentz Creutz (Kuylenstierna 1908:I25).

Få har broderat ut berättelsen av den fallne sjöhjälten som Kuylenstierna och i så spänstig berättarstil. Han skriver (Kuylenstierna 1908:I32):

Claes Johansson Uggla är en af svenska flottans vackraste, mest tilltalande gestalter. Han fick till svenska flottans olycka aldrig tillfälle att som högsta befälhavare föra befäl i rangerad batalj, men han gaf genom sin hjältemodiga och hopplösa strid på "Svärdet" ett exempel på äkta sjömannamod och hängifvenhet för flaggan, ett exempel öfver vilket svenska flottan i alla tider kan känna sig stolt.

Skepp blir berömda om deras befälhavare blir det. De olika officerarna har i berättelserna om sjötåget 1676 iklätts ganska olika, men samtidigt stereotypa, roller. Här finns den skicklige och hårdföre administratören och totalt oduglige sjömannen Creutz, den ärevördige sjöhjälten Claes Uggla och slutligen de båda oduglingarna Christer Boije och Ewert Haas på Riksäpplet. Dessa eftermälen formulerades inom flottans egen historieskrivning, men har därefter fortplantats av den bredare historieintresserade allmänheten.

Idag är regalskeppet Kronan, tack vare omfattande undervattensarkeologiska undersökningar och en påkostad utställning på Kalmar läns museum, det av skeppen som allmänheten bäst känner till. Men under många år var det Svärdet och Uggla som hade de framskjutna rollerna i översiktsverken om Sveriges historia. Creutz ombord på Kronan får bära ansvaret för den oförsiktiga vändningen av sitt skepp, som banade väg för den kedja av missöden som drabbade flottan år I676. Frågan är hur detta påverkat minnet, värderingen och hanteringen av deras skepp. Kronan, Svärdet och Riksäpplet finns ju faktiskt kvar än idag.

Att det saknas en storvulen nationell hjälteberättelse om Riksäpplet är dock endast en del av förklaringen till att vraket i stort sett förbigåtts. Det finns nämligen en annan kategori hjältar som påverkar värderingen av olika vrak. Här rör det sig inte om vare sig amiraler eller historiker och arkeologer, utan om vrakletare. 


\section{Hjältar och vrak}

Förekomsten av hjältar och äventyrare inom arkeologin är välkänd. Steven Spielbergs filmkaraktär Indiana Jones är förmodligen världens mest berömde arkeolog (se diskussion hos Holtorf 2007:62-83). Samtliga fyra filmer om den med piska, pistol och hatt utstyrde vetenskapsmannen är uppbyggda med ungefär samma dramaturgi. Indiana Jones är besatt av letandet efter ett särskilt, välkänt men ändå ack så borttappat, historiskt föremål. Den första filmen hette i svensk översättning Jakten på den försvunna skatten. Titeln fungerar utmärkt som rubrik till merparten av de vrakletarexpeditioner som ägt rum i syfte att lokalisera lämningarna efter välbekanta historiska skeppsvrak (jfr diskussion hos Wijkander 2007:65-67, Ransley 2005:624). Det är egentligen ganska märkligt att $\mathrm{dr}$ Jones inte porträtterats som vrakletare.

Carl Olof Cederlund menar med stöd i den amerikanske mytforskaren Joseph Campbells arbete The Hero with a Thousand Faces (1949) att hjälten genomgår en serie faser och att dessa skildras som en resa, verklig eller abstrakt. Hjältens första uppgift är att dra sig tillbaka från världen till en närmast andlig existens där hen möter många svårigheter som ska bemästras. En hjälte är således en person som lyckas tänja på sina egna personliga begränsningar. En hjälte vågar sig bort från vardagens värld in i en värld med övernaturliga under, där fantastiska krafter ska bekämpas. När en avgörande seger har vunnits kan hjälten återvända till världen med en förmåga att skänka människorna välsignelse (efter Cederlund 1997:49-51, jfr Campbell 1949).

Även i berättelsen om regalskeppet Vasa, såsom den förmedlas med böcker, dokumentärfilmer och inte minst med själva Vasamuseet, ingår upptäckten som ett centralt tema. Hjälten heter Anders Franzén, han som med en dåres envishet propplodade och återfann skatten - nationalklenoden Vasa - på Strömmens botten. Franzén brukade inte uppträda med hatt och piska. Däremot berättar han i flera intervjuer om den solblekta jacka som han bar den dagen då han, beväpnad med sitt propplod, lyckades genomborra det gamla regalskeppet, 30 meter under snurrebåten.

Anders Franzén hade ett tydligt fokus på just berömda skepp, sådana som var väl belysta genom skriftliga källor och som också intog centrala platser i Sveriges historia. Han har i flera sammanhang motiverat sitt ointresse för handelsfartyg på följande sätt (Franzén, I982:6, min kursivering): 
Ett handelsfartyg består till största delen av sin last och spannmål, ved, guld, tjära, porslin och tusen andra varor blir ju knappast sjöhistoria för att de råkat åka båt [...].

I det militära har det ju alltid skrivits mycket [...] under det att handelssjöfarten [...] producerat mycket fåtaliga dokument.

Mycket finns givetvis att anföra kring Franzéns argumentation (se t.ex. Eriksson 20I4a:26-28), men det viktiga är att den potential han såg i sjunkna skepp inte alls låg i det materiella, i själva skeppsvraken, utan i de skriftliga källorna. Franzéns urvalsprincip - fokus på kända skepp - gjorde att verksamheten kom att kretsa kring kungar och krig. Som visats av arkeologen Carl Olof Cederlund i olika sammanhang har denna form av vrakforskning tydligt nationalistiska förtecken och tenderar att upprepa en traditionell konservativ historiesyn (se omfattande diskussion hos Cederlund 1994; 1997; Arnstad 2009).

Sensationella vrakupptäckter bygger således på två komponenter. För det första måste vraket vara välkänt och helst kunna förknippas med en känd historisk person, när det gäller skeppsvrak rör det sig oftast om en kung eller välkänd adelsman eller ett skeende som kan kännas igen av nästan vem som helst utan djupare kunskaper om det förflutna. Skeppet måste med andra ord kunna passas in på en befintlig plats i en redan allmänt känd historia. För det andra måste skeppet givetvis vara försvunnet, men ibland räcker det med att hävda att det var försvunnet (jfr Cederlund 2006:I25-I40; 20I 2:9-64). Att vraket plötsligt uppdagas blir som en nästan kuslig påhälsning från det förflutna (se även Arnshav \& McWilliams 2015:57-64).

Arkeologen Matthew Harpster har undersökt hur skeppsvrakens kulturhistoriska sammanhang fastställs och menar att kontexten existerar oberoende av själva vrakfyndet. Själva vrakets kunskapsbidrag är i sammanhanget försumbart. Den historiska kontexten är i stort sett densamma efter fyndet som före (Harpster 2013). Arkeologin reduceras till en rapport om en dykexpedition, en ritual och en ursäkt för de inblandade att vältra sig i och för evigt förknippas med en välbekant historisk episod.

Den ton som slås an när ett välbekant vrak påträffas låter som ett kraftfullt eko av Kuylenstiernas och kung Oscars storslagna framställningar. I den mediala rapporteringen kring dykningarna på skeppet Mars påtalades bland annat (Expr. 2013-07-22): 
Vasa sjönk av en vindpust. Mars av två dagars enorma och väldigt hemska drabbningar till sjöss. När hon sjönk gjorde hon det hon var byggd att göra. Det är ingen kapitulation av feghet, utan extrem tapperhet. Man slog tillbaka tre anfallsvågor innan man blev övermäktiga.

Ofta är det just denna form av plötsliga upptäckter av historiskt välbekanta och kända vrak som sparkar igång projekt. Om vi håller oss till Östersjön kan Kronan, Vasa och Mars nämnas som projekt vilka tillkommit efter att vraken under sensationsartade omständigheter gjort återtåg in i det allmänna nutida medvetandet.

Upptäckarnas idoga slit och letande fungerar som en inträdesrit till ett nytt tillstånd och en hjältestatus. Efter ett strävsamt sökande i det kalla outforskade och mörka havet återvänder de till civilisationen krönta av framgången i jakten på den försvunna skatten.

Klassiska hjältar äras enligt traditionella belöningssystem. Helst med audiens hos självaste kungen. Sveriges förre kung Gustaf VI Adolf hade ett väldokumenterat arkeologiskt intresse (se t.ex. Mark 2004) och hans engagemang i bärgningen och utgrävningen av Vasa är välkänt. De gulnade filmsekvenserna som visar hur den energiske och driftige entreprenören Franzén skakar hand med monarken och hur de båda kliver ombord på det nyligen bärgade regalskeppet är ett stående inslag $\mathrm{i}$ de senaste 50 årens Vasadokumentärer (se diskussion hos Arnstad 2009). Sveriges nuvarande kung tycks även ha attraherats av själva dykningen. Regalskeppsarkeologi är således en av alla de verksamheter som hjälper till med att reproducera monarkin (jfr diskussion hos Frihammar 20I0).

Svärdet och amiral Uggla intog den framskjutna positionen i framställningarna av slaget vid Öland. År I980 lokaliserade Anders Franzén tillsammans med några medarbetare regalskeppet Kronan. Över 35 år av kontinuerligt marinarkeologiskt fältarbete på Kronans vrak kan sägas ha blivit såväl Kronans som Lorentz Creutz sentida renässans. Kronan kan dock aldrig bli ett hjälteskepp som Svärdet. Skeppet har i stället erhållit sin berömmelse i egenskap av ett slags skattskepp. När vraket efter Svärdet så småningom påträffades så sent som 20I I rapporterade dagstidningarna att det var tveksamt om det fanns några egentliga skatter ombord. På Kronan har man däremot hittat "två guldskatter och tre gömmor med silver. Silvret vägde 70 kilo" ( $A B$ 20I I-I I-I5).

Den största skillnaden mellan Riksäpplet och de båda utanför Öland förlista skeppen, är att Riksäpplet aldrig varit försvunnet. Vraket har 
blivit en integrerad del av landskapet. Skäret mot vilket bordläggningen krossades har efter händelsen kommit att kallas för just Äpplet och den lilla gråstensknallen kommunicerar skeppets position på varenda karta och sjökort över Dalarö med omnejd. Som vrak är Riksäpplet så välbekant och trivialt att det knappast märks. Det är en brädhög bland de betydligt mer välbevarade vraken i närområdet.

Det är mot denna skisserade historiska bakgrund som paradoxen Riksäpplet måste ses. I skrivande stund pågår diskussioner om huruvida vraket efter Svärdet ska undersökas, ett vrak som ligger ännu längre ut till havs än Kronan och på ännu större djup. Det är således de vrak som ligger på otillgängliga platser, som kräver speciell apparatur för att lokaliseras och såväl mod som avancerad utrustning för att besökas, som ägnas uppmärksamhet. Riksäpplet ligger alltjämt outforskat, nästan framför näsan på oss. 